ON THE DISTRIBUTION OF BOLITOGLOSSA ALTAMAZONICA AND

\title{
B. PERUVIANA (CAUDATA: PLETHODONTIDAE) IN THE PERUVIAN AMAZON WITH OBSERVATIONS ON THEIR ECOLOGY AND CONSERVATION
}

\author{
Axel Hernandez \\ University Pasquale Paoli of Corsica, France \\ e-mail: hernandez.axel.1989@gmail.com
}

Received: 15.03.2018

\begin{abstract}
We report ecological observations of Bolitoglossa altamazonica and B. peruviana in the Peruvian Amazon with suggestions on their conservation. Two localities are provided for both species in one protected area, AllpahuyoMishana National Reserve and in Puerto Almendra near the city of Iquitos, northern Peru. A different type of $B$. altamazonica was also discovered in Allpahuyo-Mishana. It is similar to B. madeira with a reddish coloration on the dorsal parts. Another «grey» type was also reported living between Puno and Madre de Dios departments at higher elevations. However, all the specimens found through their range in Peru have shown colour variation which complicates species identification. New taxonomic studies are needed to confirm their status. The Peruvian salamanders appear to be semi-arboreal species living in primary unflooded terra firme rainforests near water bodies where humidity is high at lower elevations as previously reported (96-118 $\mathrm{m}$ a.s.1.). Despite most of the Bolitoglossa species occur in protected areas, a deadly threat was recently reported in frogs (Batrachochytridium dendrobatidis) that may cause loss of salamanders in Peru. For example during our field surveys we were unable to observe $B$. digitigrada. New assessments are urgently needed for the protection and conservation of Peruvian salamanders. Data on biology, ecology and environmental parameters are also lacking to really protect their microhabitats, and to establish suitable ex situ keeping and breeding programs with the difficult perspective of subsequent reintroduction.
\end{abstract}

Key words: Bolitoglossa, conservation, cryptic biodiversity, ecology, Peruvian Amazon, Plethodontidae, South America, Urodela

The Nauta mushroomtongue salamander, Bolitoglossa altamazonica (Cope, 1874) is a tropical salamander : that occurs at altitudes between 200 and $1500 \mathrm{~m}$ a.s.l. in primary unflooded terra firme forest, secondary forest, and floodplain forest on the oriental side of the Andes, from Venezuela to central Bolivia, through Amazonian areas of Columbia, Ecuador, Peru to the extreme western of Brazil (Brcko et al., 2013; Elmer et al., 2013; Raffaëlli, 2013; AmphibiaWeb, 2018). This taxon is considered as a species complex which shows high levels of morphological similarity and the absence of diagnostic characteristics within populations (Brcko et al. 2013; Raffaëlli, 2013; Wake, pers. com.). However, according to Brcko et al. (2013), $B$. altamazonica is a moderately large and slender species that can be distinguished from all other Neotropical salamanders species by the presence of extensive digital webbing (with digits completely webbed), 13 costal grooves between the limbs and the absence of a sublingual fold.

The Peru mushroomtongue salamander, Bolitoglossa peruviana (Boulenger, 1883) is a small salamander species, endemic to Peru. It is found in the premontane and lowland rainforests within the Andean Piedmont, along the Amazonian slopes of San
Martin (Moyobamba) and of Loreto region, north and east of Peru, between $200 \mathrm{~m}$ and $800 \mathrm{~m}$ a.s.l. (Raffaëlli, 2013; Hernandez, 2016; AmphibiaWeb, 2018). According to Raffaëlli (2013), this taxon is probably a complex of species. The snout-vent length (SVL) is $4.2 \mathrm{~cm}$. The fingers and the toes are almost entirely webbed; there are numerous teeth on the maxillary (contrary to B. chica Brame and Wake, 1963 and $B$. paraensis (Unterstein, 1930)). In the original description, Boulenger (1883) described the species as having light brown dorsal parts with brown stripes of low contrast, and light brown ventral parts while other individuals as described later by Brame \& Wake (1963, 1972) and Wake \& Brame (1963) were completely black with brown stripes, having a white snout and a large white spot between the eyes.

We report here two localities discovered during our field work in Peru (6-8 April 2014). Three specimens of Bolitoglossa altamazonica were found in Puerto Almendra, Loreto region, northern Peru $\left(3^{\circ} 49^{\prime} 28.33^{\prime \prime} \mathrm{S}, 7^{\circ} 21^{\prime} 31.76^{\prime \prime} \mathrm{W}\right)$ at $96 \mathrm{~m}$ a.s.l. while $B$. peruviana and one different morphotype of $B$. cf. altamazonica were found in Allpahuayo-Mishana, Loreto region, northern Peru ( $\left.3^{\circ} 56^{\prime} 8.66^{\prime \prime} \mathrm{S}, 7^{\circ} 27^{\prime} 23.39^{\prime \prime} \mathrm{W}\right)$ at $118 \mathrm{~m}$ a.s.1. which lies on the right bank of Rio Nanay (Fig. 1). 


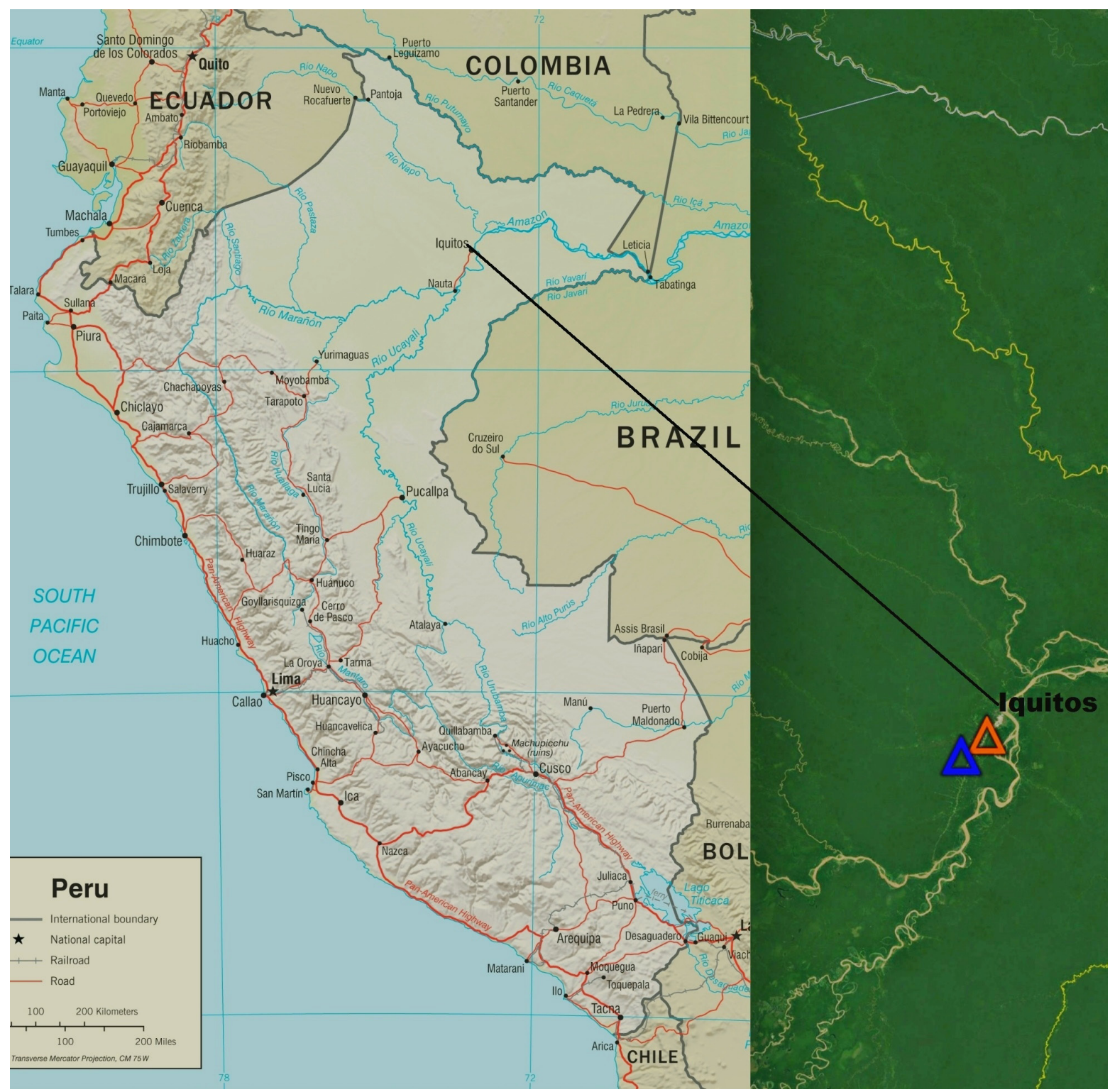

Fig. 1. Localities for species of Bolitoglossa altamazonica complex discovered in the Loreto region. Orange triangle - Puerto Almentra; blue triangle - Allpahuayo Mishana.

The locality in Puerto Almendra has disturbed primary lowland rainforests on white-sand soils mixed with clay soils characterised by sclerophyll leaves resistant to decomposition. Black-water forests are also present. We observed both species in these particular primary lowland forests which are characterised by presenting a variable canopy height of about 15-30 $\mathrm{m}$ and where stagnant water can be found in some areas (Fig. 2A). As to the floristic composition, Malvaciae (Pachira brevipes (A. Robyns) W.S. Alverson), Fabaceae and Clusiaceae are the most common tree families there. Two adults and one juvenile were discovered being active at night on a leaf of a bush at 1.2 $\mathrm{m}$ to $1.6 \mathrm{~m}$ above the ground, close to a permanent stream in the forest (Fig. 2B, Fig. 3C).

This last locality is similar to Allpahuayo-Mishana where $B$. peruviana was found on the ground near a pond (Fig. 3B) while one adult of B. cf. al- tamazonica was found on a large leaf at $1.8 \mathrm{~m}$ above the ground (Fig. 3A). The presence of small streams or ponds in all the observed microhabitats indicate a general preference for the species to moist or highly humid areas of the Amazon forests. The two localities benefit from a humid subtropical climate. This region has distinct seasonal variation in rainfall. Most rainfall occurred from January to June, with several high peaks from March to April. As to the temperatures August to October correspond to the drier season (Madigosky \& Vatnick, 2000). We know that salamander reproductive behaviour is severely affected by rainfall which increases humidity (Correa et al., 2012; Correa \& Rodrigues, 2017). The Peruvian species probably breed during the hard rain season, between March up to June which is congruent with our finding of a $B$. altamazonica juvenile in Puerta Almendra (Fig. 2C). New studies are needed to confirm 
this hypothesis in the Loreto region. The locality for B. altamazonica in Puerto Almendra is $10 \mathrm{~km}$ north from Allpahuayo-Mishana, a nature reserve which is a protected national area for biodiversity, and 20 $\mathrm{km}$ straight southwest from Iquitos city. The site is located at $80 \mathrm{~km}$ north from Nauta, the type locality (terra typical) of this species.

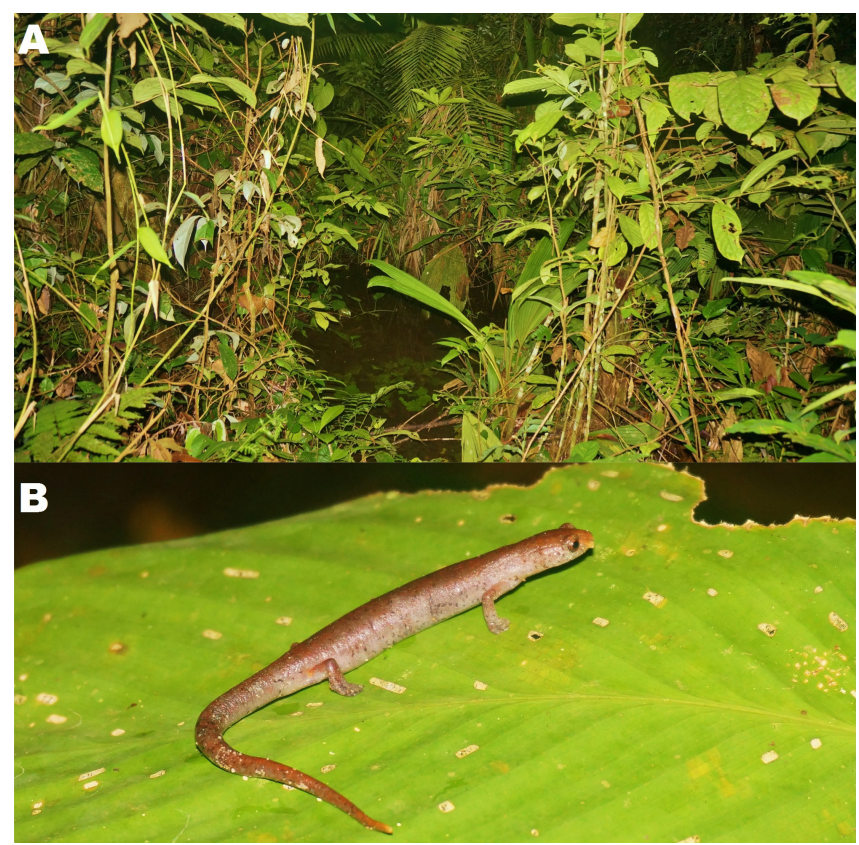

Fig. 2. A. Microhabitat showing typical primary lowland forest which is characterised by having a variable canopy height of about 15-30 m and where stagnant water can be found in some areas. B. One adult specimen of Bolitoglossa altamazonica found at night on a leaf of a bush at $1.2 \mathrm{~m}$ to $1.6 \mathrm{~m}$ above the ground, close to a permanent stream in the forest. Photos: Axel Hernandez.

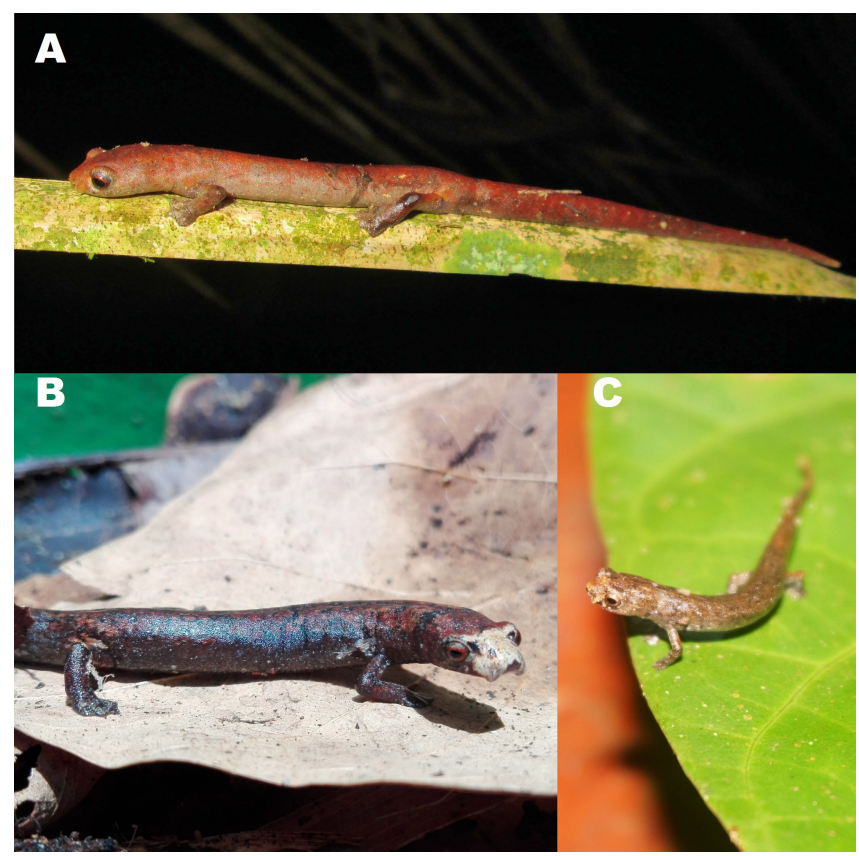

Fig. 3. A. An adult specimen of Bolitoglossa cf. altamazonica discovered on a large leaf at $1.8 \mathrm{~m}$ above the ground in Allpahuayo-Mishana National Reserve, Loreto region, Peru. B. Individual of $B$. peruviana found on the ground near a pond in the same locality. C. Juvenile of B. altamazonica from Puerto Almendra, Loreto region, Peru. Photos: Axel Hernandez.
The locality for B. peruviana is in the AllpahuayoMishana National Reserve which is under governmental special protection. The species was previously reported from this area (Rivera et al., 2003). Our findings show that both species occur at lower elevation than the one that was previously reported and we noticed that these species were always found in the proximity of little waterlogged areas in primary lowland forests. This observation is interesting because this type of microhabitat hosts a high density of mosquitoes, dipterans and coleopterans which could represent important food resources as previously reported for other sister species within the Amazonian forest (Río-García et al., 2014). Bolitoglossa altamazonica has semi arboreal habits as previously reported: the species is often observed on the leaf litter but also on the leaves especially during the nighttime. Ground surface activity is mainly related to seasonal rainfall (Ortega et al., 2009; Neckel-Oliveira et al. 2011; Raffaëlli, 2013). Finally, the Peruvian Amazon has many cryptic salamander populations that are poorly known to date (Elmer et al., 2013). The taxonomic status of some forms needs absolutely new assessments; this is the case for $B$. cf. altamazonica, but also for populations on the southern slopes of the Andes, B. cf. altamazonica, from Cerros del Távara and Manu, located between Puno and Madre de Dios departments at higher elevations. The latter is characterised by a general silver grey colouration with an orange to brownish colour on the dorsal parts while the different type observed in Loreto looks like to B. madeira at least for the colouration (Fig. 2A). In addition, all the observed specimens that were found show colour variation and a conservative morphology through their distribution range which severely complicates the identification of species (Brcko et al., 2013). That's why our visual (and morphological) identification needs to be corroborated by genetic data. Up to now, only three taxa are known to occur in this large area including $B$. altamazonica, $B$. peruviana and $B$. digitigrada. Unfortunately, during our field surveys we were unable to observe, B. digitigrada (Hernandez, 2016). Lastly, these species have fragmented populations through the Amazon region. Most of the populations occur in protected areas such as the AllpahuayoMishana National Reserve. On the other hand, another possible major threat for these species has recently been identified in some Peruvian frogs: Batrachochytridium dendrobatidis (Kosch et al., 2012).

Salamanders of the genus Bolitoglossa are known to be sensitive to this fungus and the infected amphibians are then rendered unable to breathe via the skin, they will dry up, and die usually within a short period (Pasmans et al., 2004; Kolby et al., 2010; Stark et al., 
2017). However, there are some areas in the Amazon with no evidence of this fungal infection, even on anurans and no infected neotropical salamanders were found up to date in the Loreto region. New studies are needed to determine the presence of this fungus in this Hotspot region. In Latin America, some regions have already lost nearly $80 \%$ of their amphibian populations and no solution has been found to date to save infected populations of amphibians in the wild, in the meantime contamination continues to progress all over the world. It is suggested to maintain captive populations of amphibians, for example in ex situ breeding centres that would allow studying the pathogen fungus in order to find effective treatments, but also to maintain endangered species with the option of subsequent reintroduction in the wild (Raffaëlli, 2013; Hernandez, 2017). To date, nothing has been done to protect the highly diverse and endangered genus Bolitoglossa in South America (Hernandez, 2016, 2017). Further studies are urgently needed to understand the intraspecific evolution and actual status of B. altamazonica and $B$. peruviana including new cryptic neotropical salamander populations and further to understand their specific ecological requirements so as to establish suitable keeping and breeding programs for successful conservation purposes.

\section{Acknowledgements}

I want to express my particular thanks to Jérôme Maran for his guidance. I also thank Emmanuel Jelsch for his useful remarks, Jean Raffaëlli and David B. Wake for their advices and interest.

\section{References}

AmphibiaWeb. 2018. AmphibiaWeb: Information on amphibian and conservation. Electronic Database accessible at http:// amphibiaweb.org/. Museum of Vertebrate Zoology, University of California at Berkeley. Retrieved: 30 January, 2018.

Boulenger G.A. 1883. New reptiles and amphibians. Annals and Magazine of Natural History 5: 165.

Brcko I.C., Hoogmoed M.S., Neckel-Oliveira S. 2013. Taxonomy and distribution of the salamander genus Bolitoglossa Duméril. Zootaxa 3686(4): 401-431.

Brame A.H., Wake D.B. 1963. The salamanders of South America. Natural History Museum of Los Angeles County - Contributions in Science 69: 1-72.

Brame A.H., Wake D.B. 1972. New species of salamanders (genus Bolitoglossa) from Colombia, Ecuador and Panama. Natural History Museum of Los Angeles County - Contributions in Science 219: 1-34.

Correa F.S., Neckel-Oliveira S., Rodrigues L.C. 2012. Influence of climatic variables on the abundance of a Brazilian salamander (Bolitoglossa paraensis) in Santa Bárbara do Pará, Brazil. South American Journal of Herpetology 7(1): 41-46. DOI: 10.2994/057.007.0105
Correa F.S., Rodrigues L.C. 2017. On the distribution of Neotropical climbing salamanders (Bolitoglossa paraensis) in a forest fragment of the eastern Amazon. Salamandra 53: 445-450.

Elmer K.R., Bonett R.M., Wake D.B., Lougheed S.C. 2013. Early Miocene origin and cryptic diversification of South American salamanders. BMC Evolutionary Biology 13: 59. DOI: 10.1186/1471-2148-13-59

Hernandez A. 2016. Etude sur les Urodèles en voie de disparition. Paris: Éditions Édilivre. 120 p.

Hernandez A. 2017. Les Urodèles du Maroc: Pleurodeles waltl, Salamandra algira tingitana, S. algira splendens et $S$. algira spelaea (Caudata: Salamandridae), Histoire naturelle, taxinomie, écologie et perspectives conservatoires. AFT, Revue Francophone d'Herpétoculture, Situla 30: 30-48.

Madigosky S.R., Vatnick I. 2000. Microclimatic Characteristics of a Primary Tropical Amazonian Rain Forest, Aceer, Iquitos, Peru. Selbyana 21(1/2): 165-172.

Neckel-Oliveira S., Sarmento J.F., Galatti U., Suárez P., Lima C., Lima A.A., Fáveri S.B. 2011. Reproductive traits of the Brazilian salamander Bolitoglossa paraensis (Urodela: Plethodontidae). Copeia 3: 457462. DOI: $10.1643 / \mathrm{CE}-08-219$

Ortega J.E., Monares-Riaño J.M., RamÍrez-Pinilla M.P. 2009. Reproductive activity, diet, and microhabitat use in Bolitoglossa nicefori (Caudata: Plethodontidae). Journal of Herpetology 43(1): 1-10. DOI: 10.1670/07-250R2.1

Kolby J.E., Padgett-Flohr G.E., Field R. 2010. Amphibian chytrid fungus Batrachochytrium dendrobatidis in $\mathrm{Cu}-$ suco national Park, Honduras. Diseases of Aquatic Organisms 92(2-3): 245-251. DOI: 10.3354/dao02055

Kosch T.A., Morales V., Summers K. 2012. Batrachochytrium dendrobatidis in Peru. Herpetological Review 43(2): 288-293.

Pasmans F., Zwart P., Hyatt A.D. 2004. Chytridiomycosis in the Central American bolitoglossine salamander (Bolitoglossa dofleini). Veterinary Record 154(5): 153-153. DOI: $10.1136 /$ vr.154.5.153

Raffaëlli J. 2013. Les Urodèles du monde. Penclen: Deuxième Édition. $480 \mathrm{p}$.

Río-García J.S.D., Serrano-Cardozo V.H., Ramírez-Pinilla M.P. 2014. Diet and microhabitat use of Bolitoglossa cf. pandi (Caudata: Plethodontidae) from the Cordillera Oriental of Colombia. South American Journal of Herpetology 9(1): 52-61. DOI: 10.2994/ SAJH-D-13-00031.1

Rivera C., von May R., Aguilar C., Arista I., Curo A., Schulte R. 2003. Una evaluación preliminar de la herpetofauna en la Zona Reservada Allpahuayo-Mishana, Loreto. Perú. Folia Amazónica 14(1): 139-148. DOI: 10.24841/fa.v14i1.161

Stark T., Laurijssens C., Weterings M., Martel A., Köhler G., Pasmans F. 2017. Prevalence of Batrachochytrium dendrobatidis in a Nicaraguan, micro-endemic Neotropical salamander, Bolitoglossa mombachoensis. Amphibia-Reptilia 38(1): 102-107. DOI: 10.1163/15685381-00003077

Wake D.B., Brame A.H. 1963. The status of the plethodontid salamanders genera Bolitoglossa and Magnadigita. Copeia 1963(2): 382-387. DOI: 10.2307/1441357 
О РАСПРОСТРАНЕНИИ ВOLITOGLOSSA ALTAMAZONICA И B. PERUVIANA (CAUDATA: PLETHODONTIDAE) В ПЕРУАНСКОЙ АМАЗОНИИ С ЗАМЕЧАНИЯМИ ОБ ИХ ЭКОЛОГИИ И СОХРАНЕНИИ

\author{
А. Эрнандес \\ Университет Корсики, Франция \\ e-mail: hernandez.axel.1989@gmail.com
}

\begin{abstract}
Мы сообщаем об экологических наблюдениях Bolitoglossa altamazonica и B. peruviana в Перуанской Амазонии с предложениями по их сохранению. Два местонахождения приводятся для обоих видов в одной особо охраняемой природной территории, Национальном заповеднике Аллпахуйо-Мишана, и в ПуэртоАльмендре недалеко от города Икитос на севере Перу. Другой тип B. altamazonica также был обнаружен в Аллпахуйо-Мишана. Он похож на B. madeira с красноватой окраской на дорзальной части. Также сообщалось о проживании другого «серого» типа между районами Пуно и Мадре де Диос в более высокой местности. Однако все образцы, обнаруженные в пределах их ареала в Перу, показали изменчивость в окраске, что усложняет видовую идентификацию. Необходимы новые таксономические исследования для подтверждения их статуса. Перуанские саламандры, по-видимому, являются полудесными видами, обитающими в первичных незатапливаемых тропических лесах у водоемов, где влажность высока на более низких высотах, как сообщалось ранее (96-118 м н.у.м.). Несмотря на то, что большинство видов рода Bolitoglossa встречается на ООПТ, недавно была обнаружена угроза их существованию со стороны лягушек (Batrachochytridium dendrobatidis), которые могут стать причиной их исчезновения саламандр в Перу. Например, во время полевых исследований мы не смогли обнаружить вид B. digitigrada. В ближайшее же время необходимо проведение новой оценки защиты и сохранения перуанских саламандр. Данные по биологии, экологии и параметрам окружающей среды также отсутствуют. Их наличие способствовало бы сохранению их микроместообитаний и созданию подходящих программы сохранения и разведения ex situ с перспективой последующей реинтродукции.
\end{abstract}

Ключевые слова: Bolitoglossa, Plethodontidae, Urodela, Перуанская Амазония, скрытое биоразнообразие, сохранение, Южная Америка, экология 